\title{
New combinations in PSeudognaphalium (Gnaphalieae-Asteraceae) Of Mexico
}

\author{
Oscar HinOJOSA-ESPINOSA Y José LUIS VILLASEÑOR ${ }^{1}$ \\ Departamento de Botánica, Instituto de Biología, Universidad Nacional Autónoma de México, México, D.F., México \\ 'Corresponding author: vrios@ib.unam.mx
}

\begin{abstract}
In a broad sense, Gnaphalium L. is a heterogeneous and polyphyletic genus. Pseudognaphalium Kirp. is one of the many segregated genera from Gnaphalium which have been proposed to obtain subgroups that are better defined and presumably monophyletic. Although most Mexican species of Gnaphalium s.l. have been transferred to Pseudognaphalium, the combinations so far proposed do not include a few Mexican taxa that truly belong in Pseudognaphalium. In this paper, the differences between Gnaphalium s.s. and Pseudognaphalium are briefly addressed, and the transfer of two Mexican species and three varieties from Gnaphalium to Pseudognaphalium are presented.
\end{abstract}

Key Words: generic segregate, Gnaphalium, Mexican composites, taxonomy.

Resumen: En sentido amplio, Gnaphalium L. es un género heterogéneo y polifilético. Pseudognaphalium Kirp. es uno de varios géneros segregados, a partir de Gnaphalium, que se han propuesto para obtener subgrupos mejor definidos y presumiblemente monofiléticos. La mayoría de las especies mexicanas de Gnaphalium s.l. han sido transferidas al género Pseudognaphalium; sin embargo, las combinaciones propuestas hasta el momento no cubren algunos taxones mexicanos que pertenecen a Pseudognaphalium. En este trabajo se explican brevemente las diferencias entre Gnaphalium s.s. y Pseudognaphalium, y se presentan las transferencias de dos especies y tres variedades mexicanas de Gnaphalium a Pseudognaphalium.

Palabras clave: compuestas mexicanas, Gnaphalium, segregados genéricos, taxonomía.

T he tribe Gnaphalieae is one of the most diverse groups within the Asteraceae, comprising 180 genera and 2,000 species (Anderberg, 1994). Although Gnaphalieae are cosmopolitans, they are especially rich in South America, South Africa, and Australia (Anderberg, 1994; Ward et al., 2009). Traditionally, the members of the Gnaphalieae were included in the tribe Inuleae, until it was shown that the latter tribe was not monophyletic (Anderberg, 1989). Therefore, in place of a single tribe that was recognized in the past, Anderberg (1989) proposed to recognize three tribes, Inuleae, Gnaphalieae, and Plucheeae. However, at present only the tribes Inuleae and Gnaphalieae are recognized, whereas the Plucheeae is included in the Inuleae again (Funk et al., 2009).

The taxonomy of the tribe Gnaphalieae has been problematic (Anderberg, 1991). Among the major issues are: the definition and delimitation of diverse and heterogeneous genera, such as Helichrysum Mill. and Gnaphalium L. Anderberg (1991) concluded, based on a cladistic analysis, that both genera if they are considered in a broad sense, are polyphyletic. Nevertheless, in many contributions to the Mexican flora (e.g. McVaugh, 1984; Espinosa, 2001), Gnaphalium has been considered in a broad sense (Helichrysum is not present in Mexico).

Pseudognaphalium Kirp. is a generic segregate from Gnaphalium. At first, Pseudognaphalium was proposed as a monotypic genus based on the Mexican species $G$. oxyphyllum DC. (Kirpicznikov and Kuprijanova, 1950). Afterwards, Hilliard and Burtt (1981) transferred ten species from Gnaphalium to Pseudognaphalium (none of them was a Mexican species, although P. luteoalbum (L.) Hilliard \& Burtt. occurs in Mexico as an introduced species). In a systematic study of the tribe Gnaphalieae, Anderberg (1991) asserted that Pseudognaphalium is more closely related to Achyrocline DC. and Helichrysum than to Gnaphalium s.s. Consequently Anderberg (1991) transferred about 70 species more from Gnaphalium to Pseudognaphalium, including the majority of the Mexican species of Gnaphalium s.l. It is worth noting that the segregation of Pseudognaphalium from Gnaphalium (and other genera, e.g. Gamochae- 
ta Wedd.) has also been supported by recent phylogenetic analysis with molecular data (Ward et al., 2009; Schilling and Floden, 2012).

In North America, the members of Gnaphalium s.s. are annual prostrate herbs, $3-30 \mathrm{~cm}$ high, woolly, with heads arranged in glomeruliform or spiciform clusters, and a pappus dimorphic (the bristles of the female florets have acute apical cells and the bristles of the hermaphroditic florets have clavate apical cells) of distinct and easily deciduous bristles (Nesom, 2006). On the other hand, Pseudognaphalium are annuals to perennials, ascending to commonly erect, herbs or subshrubs, $15-220 \mathrm{~cm}$ high, woolly to glandular-hirsute, with heads arranged in corymbiform clusters and a pappus monomorphic (the apical cells from the bristles of the two types of florets are all subclavate) also of distinct, (mostly) easily deciduous bristles. Furthermore, the stereome (the basal cartilaginous portion of the involucral bracts) is divided in Gnaphalium, whereas in Pseudognaphalium and related genera (i.e. Achyrocline, Helichrysum), the stereome is divided or fenestrated (Anderberg, 1991; Pruski, 2012). To observe the kind of stereome, it is often necessary to place the involucral bracts in some medium which makes the tissue transparent (Anderberg, 1991). This procedure is out of the scope of this work; however, the two types of stereoms are illustrated in Hilliard and Burtt (1981). Otherwise, it has also been mentioned that Gnaphalium has the tip of the corolla purplish, whereas in Pseudognaphalium the tip of the corolla is yellowish. This is true in the majority of the cases; however, some taxa present in Mexico are an exception. For example, G. polycephalum Michx., a Mexican species retained in Gnaphalium s.s, has corollas with yellowish tips and $P$. luteoalbum has corollas with purplish tips. In addition, this character is difficult to observe in herbarium sheets, especially in old specimens.

Some Mexican species and varieties of Gnaphalium s.l., that have the characteristics of Pseudognaphalium mentioned above, were not examined by Anderberg (1991) and for this reason, the proper nomenclatural combinations were not carried out. Following the classification proposed by Anderberg (1991), we herewith transfer two species and three varieties of Mexican Gnaphalium s.l. to Pseudognaphalium.

Pseudognaphalium attenuatum (DC.) Anderb. var. sylvicola (McVaugh) Hinojosa \& Villaseñor, comb. nov. Basionym: Gnaphalium attenuatum DC. var. sylvicola McVaugh, Contr. Univ. Michigan Herb. 9: 465. 1972. TYPE: Mexico. Jalisco: Sierra de Cuale, SW of Talpa de Allende, altitude 1,800-2,250 m, 19-21 Nov 1952, McVaugh 14283 (holotype: MICH digital image!, isotypes: BM digital image!, MEXU!, NY digital image!).

Distribution. Variety known from Guatemala and Mexico (Chis., D.F., Dgo., Gro., Jal., Mex., Mich., Mor., Nay., Oax., and $\mathrm{Sin}$.).

Vegetation. In humid mountain forest, pine forest, pine-fir forest, pine-oak forest, and at the transition between tropical deciduous forest and oak forest.

Altitude. 1,200-3,050 m.

Flowering. October-March.

Pseudognaphalium ehrenbergianum (Sch. Bip. ex Klatt) Hinojosa \& Villaseñor, comb. nov. Basionym: Gnaphalium ehrenbergianum Sch. Bip. ex Klatt, Linnaea 42: 127. 1878. TYPE: Mexico. Hidalgo. Ehrenberg 24 (P fragment, digital image).

Distribution. Species endemic to Mexico (Hgo., Pue., and Ver.).

Vegetation. In humid mountain forest, oak forest, pine forest, and pine-fir forest.

Altitud. 1,300-2,200 m.

Flowering. October-January.

Pseudognaphalium hintoniorum (G.L.Nesom) Hinojosa \& Villaseñor, comb. nov. Basionym: Gnaphalium hintoniorum G.L.Nesom, Phytologia. 68: 414. 1990. TYPE: Mexico. Nuevo Leon: Municipio Galeana, Cerro Potosi, pine forest, altitude 3,350 m, 15 Oct 1969, Hinton 17263 (holotype: TEX digital image!, isotypes: HINTON digital image!, MICH digital image!).

= Gnaphalium flavocephalum G.L. Nesom, Phytologia 68: 413. 1990.

Distribution. Species endemic of Mexico (Coah., N.L., and Tams.).

Vegetation. Oak forest, pine forest, subalpine grassland, and matorral.

Altitude. 2,400-3,680 m.

Flowering. September-July.

Nesom (1990) published Gnaphalium hintoniorum and G. flavocephalum G.L. Nesom as different species, even though there are morphological and ecogeographical equivalences between the two entities. However, the holotype of G. flavocephalum (Hinton 18902 TEX digital image!) was re-identified by Nesom, in 1999, as G. hintoniorum (as can be testified by the correction label of the author on the specimen). Therefore, G. flavocephalum is considered as synonym of Pseudognaphalium hintoniorum.

Pseudognaphalium liebmannii (Sch. Bip. ex Klatt) Anderb. var. monticola (McVaugh) Hinojosa \& Villaseñor, comb. nov. Basionym: Gnaphalium vulcanicum I.M.Johnst. var. monticola McVaugh, Contr. Univ. Michigan Herb. 9: 466. 1972. TYPE: Mexico. Jalisco: 25-30 km SE of Autlán, between El Chante and Cuzalapa, pine forest, altitude 2,750 m, 20-21 March 1965, McVaugh 23126 (holotype: MICH digital image!, isotypes: CAS digital image!, ENCB!, NY digital image).

$=$ Gnaphalium liebmannii (Sch. Bip. ex Klatt) var. monticola (McVaugh) D.L. Nash, Fieldiana Bot. 36: 74. 1974.

Distribution. Variety known from Costa Rica, Guatemala 
and Mexico (Chis., D.F., Dgo., Gro., Hgo., Mex., Mich., Mor., Oax., Pue., Tlax., and Ver.).

Vegetation. Fir forest, humid pine forest, pine forest, and pine-oak forest.

Altitude. 2,500-3,500 m.

Flowering. October-April.

Pseudognaphalium oxyphyllum (DC.) Kirp. var. nataliae (F.J.Espinosa) Hinojosa \&Villaseñor, comb. nov. Basionym: Gnaphalium oxyphyllum DC. var. nataliae F.J. Espinosa, Bol. Soc. Bot. México 45: 17. 1983. TYPE: México. Estado de México: Alrededores de San Pedro Nexcapa, Amecameca, bosque de Pinus y Abies, terreno perturbado, altitud 3,000 m, 21 de septiembre de 1979, Espinosa 766 (holotipo: MEXU!, isotipo: ENCB!).

Distribution: Variety endemic of Mexico (D.F., Hgo., Mex., Mor., Pue., and Ver).

Vegetation: Fir-forest, oak forest, and pine forest.

Altitude: 2,500-3,900 m.

Flowering: October-April.

\section{Acknowledgements}

We are grateful to María del Rosario García Peña for the facilities given for consulting material stored at the type collection in the Herbario Nacional de México (MEXU). Enrique Ortiz collaborated with technical details in the managing of information. We are also thankful for the valuable suggestions and commentaries of two anonymous reviewers, one of them also helped to improve the grammatical framework of the written, and we are very grateful for that.

\section{Literature cited}

Anderberg A.A. 1989. Phylogeny and reclassification of the tribe Inuleae (Asteraceae). Canadian Journal of Botany 67:2277-2296. Anderberg A.A. 1991. Taxonomy and phylogeny of the tribe Gna- phalieae (Asteraceae). Opera Botanica 104:1-195.

Anderberg A.A. 1994. Gnaphalieae. In: Bremer K. Ed. Asteraceae. Cladistics and Classification, pp. 304-364, Timber Press, Portland.

Espinosa F.J. 2001. Gnaphalium L. In: Calderón de Rzedowski G. and Rzedowski J. Flora Fanerogámica del Valle de México. $2^{\mathrm{a}}$ ed. pp. 840-856, Instituto de Ecología, A.C., Comisión Nacional para el Conocimiento y Uso de la Biodiversidad, Pátzcuaro.

Funk V.A., Susanna A., Stuessy T.F. and Bayer R.J. 2009. Systematics, Evolution, and Biogeography of Compositae. International Association for Plant Taxonomy, University of Vienna, Vienna.

Hilliard O.M. and Burtt B.L. 1981. Some generic concepts in Compositae-Gnaphaliinae. Botanical Journal of the Linnean Society 82: 181-232.

Kirpicznikov M.E. and Kuprijanova L.A. 1950. Morphological, geographical and palynological contributions to the understanding of the genera of the subtribe Gnaphalinae (in Russian). Trudy Botanicheskogo Instituta Akademii Nauk SSSR 9:7-37.

McVaugh R. 1984. Flora Novo-Galiciana: A Descriptive Account of the Vascular Plants of Western Mexico. Vol. 12 Compositae. The University of Michigan Press. Ann Harbor.

Nesom G.L. 1990. Two new species of Gnaphalium (Asteraceae: Inuleae) from the high peaks of Northeastern México. Phytologia 68:413-417.

Nesom G.L. 2006. Gnaphalium L. In: Flora of North America Editorial Committee Eds. Flora of North America North of Mexico, pp. 428-430, Oxford University Press, New York.

Pruski J.F. 2012. Studies of neotropical Compositae-IV. Pseudognaphalium leucostegium, a new species from Huehuetenango, Guatemala, and a new combination in Chionolaena (Gnaphalieae). Phytoneuron 2012-1:1-5.

Schilling E.E. and Floden A. 2012. Barcoding the Asteraceae of Tennessee, Tribes Gnaphalieae and Inuleae. Phytoneuron 201299:1-6.

Ward J.M., Bayer R.J., Breitwieser I., Smissen R.D., GalbanyCasals M. and Unwin M. 2009. Gnaphalieae. In: Funk V.A., Susanna A., Stuessy T.F. and Bayer R.J. Eds. Systematics, Evolution, and Biogeography of Compositae, pp. 539-588, International Association for Plant Taxonomy, University of Vienna, Vienna.

Received: July 22nd, 2013

Accepted: October 10th, 2013 